\title{
IGF-I but not insulin inhibits apoptosis at a low concentration in vascular smooth muscle cells
}

\author{
R Jamali ${ }^{1}, \mathbf{M}$ Bao ${ }^{1}$ and $\mathbf{H}$ J Arnqvist ${ }^{1,2}$ \\ ${ }^{1}$ Division of Cell Biology, Department of Biomedicine and Surgery, Faculty of Health Sciences, Linköping University, Linköping, Sweden \\ ${ }^{2}$ Division of Internal Medicine, Department of Medicine and Care, Faculty of Health Sciences, Linköping University, Linköping, Sweden \\ (Requests for offprints should be addressed to H Arnqvist, Department of Biomedicine and Surgery, Division of Cell Biology, University Hospital, \\ S-581 85 Linköping, Sweden; Email: hans.arnqvist@ibk.liu.se)
}

\begin{abstract}
Apoptosis of vascular smooth muscle cells (VSMCs) is of importance in the development of diabetic angiopathy. Our aim was to evaluate the effect of insulin and IGF-I on apoptosis in VSMCs. Rat aortic VSMCs were used and apoptosis was induced by serum starvation. As apoptotic markers we measured caspase-3 activity, histoneassociated DNA fragments by ELISA and nuclear morphology by DAPI (4',6-diamidino-2-phenylindole) staining. Phosphorylation of IGF-I receptors was evaluated by Western blot. Serum starvation had increased caspase-3 activity even after $3 \mathrm{~h}$. The highest activity was found after 3-12 h. IGF-I $10^{-9} \mathrm{M}$ inhibited serum starvationinduced caspase-3 activity with a maximal effect after $12 \mathrm{~h}$. When studied after starvation for $12 \mathrm{~h}$, significant inhibitory effects on caspase-3 were found at IGF-I
\end{abstract}

concentrations of $10^{-8}-10^{-7} \mathrm{M}(P<0 \cdot 01)$ and at an insulin concentration of $10^{-6} \mathrm{M} \quad(P<0 \cdot 01)$. DNA fragmentation was detected by ELISA after $24 \mathrm{~h}$ and chromatin condensation and nuclear fragmentation by DAPI staining after 24 and $48 \mathrm{~h}$ respectively. IGF-I dose-dependently reduced apoptosis evaluated by ELISA, reaching a maximal effect at $10^{-9} \mathrm{M}$. Insulin reduced apoptosis but the effect was weaker and a higher concentration was needed. IGF-I $\left(10^{-8} \mathrm{M}\right)$ and insulin at a very high concentration $\left(10^{-6} \mathrm{M}\right)$ phosphorylated IGF-I receptors. Taken together, IGF-I and insulin have antiapoptotic effects on VSMCs but the effect of insulin is only found at high unphysiological concentration.

Journal of Endocrinology (2003) 179, 267-274

\section{Introduction}

Vascular smooth muscle cells (VSMCs) are involved in development of vascular disease by processes such as cell proliferation, migration, apoptosis and production of extracellular matrix (Davies et al. 1993, Davies 1996, Bennett \& Boyle 1998, Goetze et al. 2001). Diabetes mellitus causes a variety of abnormalities in the vascular system, affecting both micro- and macrovasculature (Donnelly et al. 2000). It has been hypothesized that the pathogenesis of diabetic vasculopathy involves abnormal regulation of VSMC apoptosis (Hall et al. 2000). Diabetes even of short duration accelerates the death of capillary cells in the retina by apoptosis (Podesta et al. 2000). In atherosclerotic disease, apoptosis of VSMCs has a critical role in plaque stability (Davies 1996, Okura et al. 2001).

Initiation of apoptosis can result from multiple stimuli such as growth factor withdrawal, cytokines, free radicals and toxins (Cohen 1994, Pollman et al. 1996). It occurs by rapid, irreversible condensation of cytoplasm, accompanied by an increase in cell density and condensation of the nuclear chromatin (Saini \& Walker 1998). Activation of the caspase cascade is responsible for many of the hallmarks of apoptosis, such as DNA fragmentation, chromatin condensation and apoptotic body formation (Janicke et al. 1998). Caspases are cysteine proteases which have an unusual specificity among proteolytic enzymes to perform highly selective proteolysis during the course of cell death (Thornberry et al. 1997, Kidd 1998). Caspases can be grouped according to their principal function: group I (caspases 1, 4, 5) are primarily involved in the processing of pro-inflammatory cytokines; group II (caspases $2,3,7$ ) act as downstream terminal effector caspases responsible for cleavage of intracellular substrates required for cellular survival, architecture and metabolic function (Chinnaiyan \& Dixit 1996, McCarthy \& Bennett 2000); group III (caspases 6, 8, 9) are involved in the cleavage and activation of group II caspases.

Activation of the insulin-like growth factor (IGF)-I receptor (IGF-IR) exerts antiapoptotic effects, protecting multiple cell types against a variety of death signals (Peruzzi et al. 1999). Suppression of IGF-I signalling induces apoptosis in vitro and in vivo (Resnicoff et al. 1994). IGF-I has an important role in the survival of VSMCs in different ways, including a marked suppression of apoptosis (Bennett et al. 1995). Also insulin has been reported 
to inhibit apoptosis in VSMCs (Jung et al. 2000, Goetze et al. 2001). There are few insulin receptors in VSMCs and it has been suggested that the effect of insulin is mediated through IGF-IRs (Lee et al. 1988, Arnqvist et al. 1995). The aim of this study was to determine the effect of IGF-I and insulin in a time- and dose-dependent manner on apoptosis in VSMCs.

\section{Materials and Methods}

\section{Cell culture}

Aortic smooth muscle cells were isolated from male Sprague-Dawley rats $(\sim 250 \mathrm{~g})$ according to Nilsson et al. (1983). Animal procedures were approved by the local ethical committee for animals. Cells were grown in Ham's medium (Invitrogen, Stockholm, Sweden) with $50 \mu \mathrm{g} / \mathrm{ml}$ ascorbic acid, $50 \mu \mathrm{g} / \mathrm{ml}$ gentamicin sulphate, $2 \mu \mathrm{g} / \mathrm{ml}$ Fungizone and 10\% new-born calf serum (NCS) (Invitrogen) in $\mathrm{F} 12$ medium ( $\mathrm{pH} 7 \cdot 4$ ) (Invitrogen) at $37^{\circ} \mathrm{C}$ and air with $5 \% \mathrm{CO}_{2}$. Trypsin (0.05\%) and EDTA (0.02\%) solution was used to passage the cells. Cells between passages three and ten were used for the experiments. The cells were characterized as smooth muscle cells according to morphological criteria (Ross 1971) and with a murine monoclonal antibody (clone asm-1, IgG2a; Boehringer Mannheim $\mathrm{GmbH}$, Mannheim, Germany) against a unique epitope of smooth muscle $\alpha$-actin, as described by Skalli et al. (1986). This type of $\alpha$-actin is specific for smooth muscle cells (Gabbiani et al. 1981). Cells grown on glass coverslips were washed twice with PBS and fixed in ice-cold acetone for $5 \mathrm{~min}$. Thereafter the cells were preincubated in $2 \%$ goat serum and $1 \%$ BSA in PBS for $15 \mathrm{~min}$, and then incubated with fluorescein-linked antimouse IgG from sheep (Amersham Pharmacia Biotech) for 30 min. A Nikon Eclipse E800 fluorescence microscope equipped with a VFM EPI-fluorescence attachment (Nikon Instruments Inc., Melville, NY, USA) was used.

\section{Morphological evaluation by DAPI \\ (4',6-diamidino-2-phenylindole) staining}

Cells were cultured in $35 \mathrm{~mm}$ Petri dishes and fixed with $4 \%$ formaldehyde, washed twice with PBS, stained with DAPI $5 \times 10^{-7} \mathrm{M}$ for $10 \mathrm{~min}$, and mounted with Vectashield with DAPI (ImmunKemi, Järfälla, Sweden). Apoptosis was quantitated by counting a total of 200 nuclei from each Petri dish and calculating the percentage of apoptotic nuclei.

\section{Determination of caspase-3 activity}

To assay caspase-3 activity, Ac-DEVD-AMC, a caspase-3 fluorogenic substrate was used (Cat. No. 66081U; BD PharMingen, BD Biosciences, Stockholm, Sweden).
Activated caspase- 3 cleaves Poly (ADD ribose) polymerase from its $116 \mathrm{kDa}$ to an $85 \mathrm{kDa}$ residual fragment. When Ac-DEVD-AMC is treated with active caspase-3, 7-amino-4-methylcoumarin (AMC) is released and monitored in a spectrofluorometer at an excitation wavelength of $380 \mathrm{~nm}$ and an emission wavelength range of 430 $460 \mathrm{~nm}$.

For analysis of caspase- 3 activity, the cells were grown in $10 \mathrm{~cm}$ Petri dishes. Near-confluent cells were starved in serum-free medium and then harvested after $0,3,6,12$, 24 and $48 \mathrm{~h}$. For evaluation of the effects of IGF-I and insulin, near-confluent cells were incubated for $12 \mathrm{~h}$ with serum-free medium and different concentrations of IGF-I $\left(10^{-11}-10^{-7} \mathrm{M}\right)$ or insulin $\left(10^{-10}-10^{-6} \mathrm{M}\right)$. As positive control, cells cultured in 10\% NCS were used. Samples were scratched off with a rubber policeman, centrifuged at $700 \mathrm{~g}$ for $10 \mathrm{~min}$, washed with PBS washing buffer recommended by the company and centrifuged at $700 \mathrm{~g}$ for $5 \mathrm{~min}$. The pellet was stored at $-70{ }^{\circ} \mathrm{C}$ until measurement. Pellets were lysed with $100 \mu \mathrm{l}$ cell lysis buffer (recommended by company) for $30 \mathrm{~min}$ on ice. Fifteen microlitres of the lysed suspension were used for protein determination (Lowry et al. 1951). The remaining lysate was incubated with $1 \mathrm{ml}$ reaction buffer $(20 \mathrm{mM}$ HEPES (pH 7·5), 10\% glycerol, $2 \mathrm{mM}$ dithiothreitol) and $20 \mu \mathrm{M}$ Ac-DEVD-AMC for $1 \mathrm{~h}$ in a shaking water-bath at $37^{\circ} \mathrm{C}$. Caspase-3 activity was expressed as arbitrary units of AMC fluorescence per microgram of protein.

\section{Detection of apoptosis by ELISA}

Apoptotic cell death was evaluated by a photometric enzyme-linked immunoassay for quantitative determination of cytoplasmic histone-associated DNA fragments (Cell Death Detection ELISA Kit; Roche Diagnostic Scandinavian AB, Stockholm, Sweden). The kit was used according to the manufacturer's instruction. Cells were cultured in 24-well plates with 40000 cell/well. After $72 \mathrm{~h}$ near-confluent cells were starved in $1 \mathrm{ml}$ serum-free medium for $24 \mathrm{~h}$ and then incubated with serum-free medium with different concentrations of IGF-I $\left(10^{-11}\right.$ $\left.10^{-7} \mathrm{M}\right)$ or insulin $\left(10^{-10}-10^{-6} \mathrm{M}\right)$ for the next $24 \mathrm{~h}$. Control cells were kept in serum-free medium. Cells were harvested including medium by scratching of the wells and centrifuged at $700 \boldsymbol{g}$ for $10 \mathrm{~min}$. The cell pellet was lysed with the incubation buffer of the kit and centrifuged to pellet cell nuclei, containing high molecular weight DNA. The supernatant containing mono-and oligonucleosomes or low molecular weight DNA was used for the rest of the assay. Anti-histone antibody containing coating buffer was added to the 96-well ELISA plates and incubated overnight at $4{ }^{\circ} \mathrm{C}$. The plates were rinsed (three times) with washing buffer and the samples were added and incubated for $90 \mathrm{~min}$. Plates were rinsed (three times) with washing buffer and the peroxidase-conjugated anti-DNA antibody was added. After incubation with peroxidase substrate 
(ABTS) from Roche, optical density of the colour reaction was measured by a spectrophotometer at $405 \mathrm{~nm}$.

\section{Western blot analysis}

VSMCs were seeded in $150 \mathrm{~mm}$ Petri dishes and cultured for 5-10 days to near confluence. After $24 \mathrm{~h}$ starvation, IGF-I $\left(10^{-8} \mathrm{M}\right)$ or insulin $\left(10^{-8}, 10^{-6} \mathrm{M}\right)$ was added to the Petri dishes, mixed gently, incubated for $10 \mathrm{~min}$ and quickly removed. Petri dishes were placed on liquid nitrogen for about $30 \mathrm{~s}$. Two millilitres of lysis buffer (Tris $20 \mathrm{mM}$ (pH 7.5), NaCl $150 \mathrm{mM}$, EDTA $5 \mathrm{mM}$, sodium deoxycholate $0 \cdot 5 \%$, Triton X-100 $0 \cdot 5 \%, \mathrm{Na}_{3} \mathrm{VO}_{4} 1 \mathrm{mM}$, aprotinin $1.5 \mu \mathrm{g} / \mathrm{ml}$, leupeptin $1.5 \mu \mathrm{g} / \mathrm{ml}$, phenylmethylsulphonylfluoride $1 \mathrm{mM}$ ) were added to Petri dishes and cell lysates left on ice for $30 \mathrm{~min}$. Cells were completely scraped off before totally thawed and transferred to prechilled tubes. Cells lysates were centrifuged at $15000 \boldsymbol{g}$ at $4{ }^{\circ} \mathrm{C}$ for $10 \mathrm{~min}$. The supernatant was transferred into other tubes. Samples were stored at $-70{ }^{\circ} \mathrm{C}$ if not used immediately.

Total protein content was measured by the bicinchoninic acid method to adjust the amount of aliquot used for subsequent experiments. To each tube of cell lysate that contained $1 \mathrm{mg}$ total protein, $2 \mu \mathrm{l}$ corresponding polyclonal antibody (anti-IGF-IR $\beta$-subunit antibody C20; Santa Cruz Biotechnology, Santa Cruz, CA, USA) were added and the test tube was kept on ice for $2 \mathrm{~h}$. Fifty microlitres of protein-A Sepharose (Pharmacia, Uppsala, Sweden) were added and gently shaken at $4{ }^{\circ} \mathrm{C}$ overnight. The immunoprecipitates were washed three times with ice-cold lysis buffer and diluted in $50 \mu \mathrm{l}$ sample buffer. Samples were separated on a 7.5\% SDS-PAGE and transferred onto a polyvinyl difluoride membrane. After blocking in $0.2 \%$ polyvinyl alcohol and $0.2 \%$ Tween in buffer (Trisma base $0 \cdot 05 \mathrm{M}, \mathrm{NaCl} 0 \cdot 15 \mathrm{M}, \mathrm{pH} 7 \cdot 5$ ), the membrane was immunoblotted using a 1:1000 dilution of the anti-IGF-IR $\beta$-subunit antibody for $2 \mathrm{~h}$ at room temperature. A monoclonal phosphotyrosine antibody (anti-phosphotyrosine antibody PY20, sc-508; Santa Cruz Biotechnology) was used to detect receptor phosphorylation. The proteins were detected with a horseradish peroxidase-linked secondary antibodies and an ECL Plus system (Amersham Pharmacia Biotech). In order to show different proteins on the same membrane, the membrane was stripped by heating to $60{ }^{\circ} \mathrm{C}$ for $30 \mathrm{~min}$ in stripping buffer containing 10\% SDS, $100 \mathrm{mM}$ 2-mercaptoethanol in $62.5 \mathrm{mM}$ Tris- $\mathrm{HCl}$.

\section{Statistical analysis}

Values are given as means \pm S.E.M. from at least four independent experiments. Statistical analysis was performed by Student's $t$-test for paired unpaired comparisons and, when multiple comparisons were made, by one-way ANOVA in conjunction with Dunnett's post-hoc test. $P<0.05$ was considered statistically significant.

\section{Results}

\section{DAPI staining}

As shown in Fig. 1A, VSMCs had intact nuclear morphology in medium with $10 \%$ NCS while cells cultured in serum-free medium for $24 \mathrm{~h}$ showed chromatin condensation (Fig. 1B). DNA fragmentation and nuclear shrinkage of VSMCs were found after starvation for $48 \mathrm{~h}$ (Fig. 1C). The percentage of apoptotic nuclei after $48 \mathrm{~h}$ was $6 \cdot 0 \pm 1 \cdot 0 \%$ in serum and $11 \cdot 8 \pm 1 \cdot 5 \%(n=6, P<0 \cdot 02)$ in serum-free media.

\section{Caspase-3 activity}

Caspase-3 activity was already increased after serum starvation for $3 \mathrm{~h}$ in VSMCs (Fig. 2). The highest activity was observed after $3-12 \mathrm{~h}$. IGF-I $10^{-9} \mathrm{M}$ reduced serum starvation-induced caspase- 3 activity with a maximal effect after $12 \mathrm{~h}$ (Fig. 3). The effect of IGF-I was of borderline significance after $6 \mathrm{~h}(P<0 \cdot 055)$ and significant after $12 \mathrm{~h}(P<0 \cdot 04)$. After starvation for 24 and $48 \mathrm{~h}$ no effect of IGF-I was found. When studied after starvation for $12 \mathrm{~h}$, significant inhibitory effects on caspase-3 were found at IGF-I concentrations of $10^{-8}-10^{-7} \mathrm{M}$ $(P<0 \cdot 01)$ and at an insulin concentration of $10^{-6} \mathrm{M}$ $(P<0 \cdot 01)$ (Fig. 4). Borderline significances were obtained for IGF-I $10^{-9} \mathrm{M}$ and insulin $10^{-7} \mathrm{M}, P<0.056$ and $P<0.058$ respectively.

\section{Antiapoptotic effect of insulin and IGF-I evaluated by ELISA}

ELISA analysis of mono- and oligonucleosomal DNA fragmentation demonstrated a high DNA fragmentation in VSMCs between 24 and $72 \mathrm{~h}$ of serum starvation compared with cells incubated with serum (Fig. 5). Cells incubated with IGF-I $\left(10^{-11}-10^{-7} \mathrm{M}\right)$ or insulin $\left(10^{-10}-10^{-6} \mathrm{M}\right)$ showed different inhibitory effects on apoptosis (Fig. 6). The highest inhibitory effects of IGF-I and insulin were seen at concentrations of $10^{-9} \mathrm{M}$ and $10^{-8} \mathrm{M}$ respectively; $P<0.003$ compared with control.

\section{Phosphorylation of IGF-IRs}

Phosphorylation of IGF-IR $\beta$-subunit was found by IGF-I $\left(10^{-8} \mathrm{M}\right)$ and insulin $\left(10^{-6} \mathrm{M}\right)($ Fig. $7 \mathrm{~A})$. A very weak band was also found with insulin $\left(10^{-8} \mathrm{M}\right)$ (Fig. 7A). Figure $7 \mathrm{~B}$ shows the gel blotted with an antibody against IGF-IR. The experiment was repeated three times with similar results. 

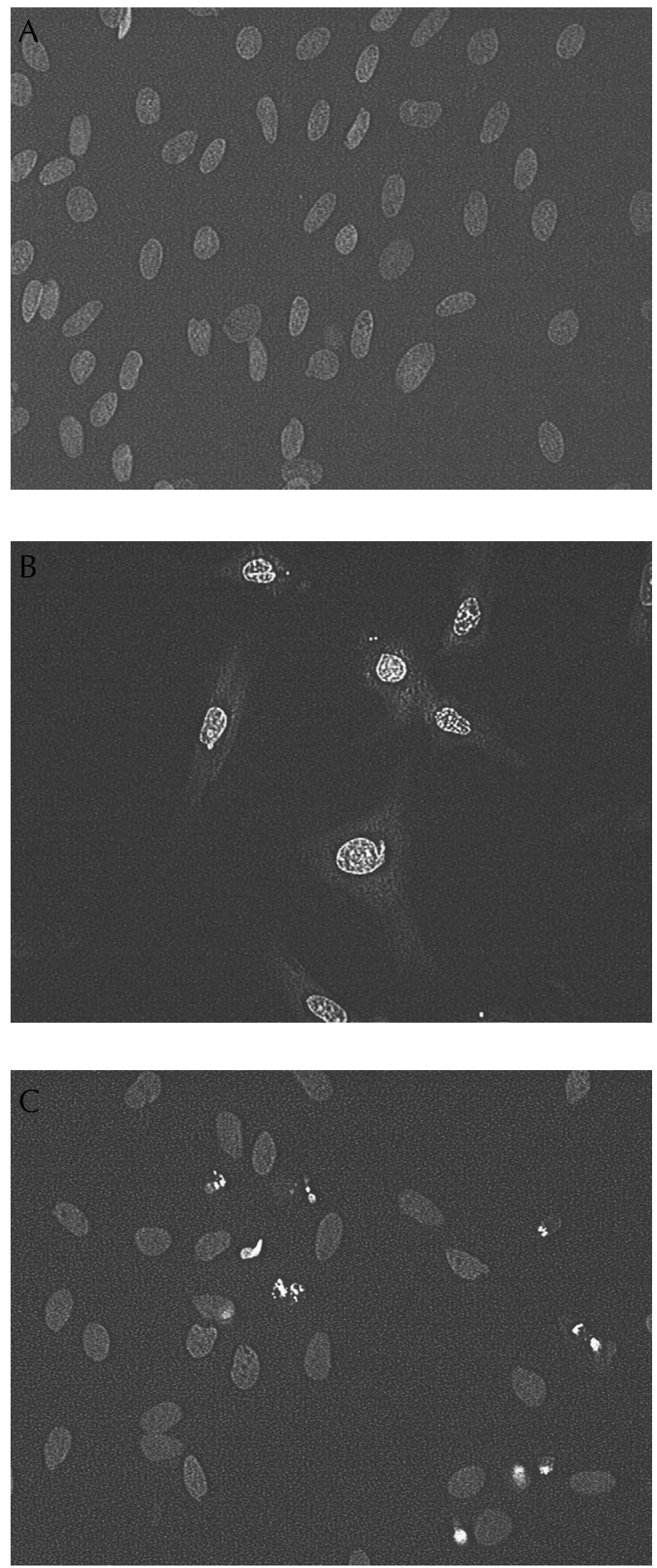

Figure 1 Morphological evidence of apoptosis in VSMCs stained with DAPI. Confluent cells were starved with serum-free medium and control cells were grown in $10 \%$ NCS. (A) Cells in $10 \%$ NCS had intact nuclei. (B) After $24 \mathrm{~h}$ in serum-free medium, nuclei showed chromatin condensation. (C) Nuclear shrinkage after serum-free medium for $48 \mathrm{~h}$.

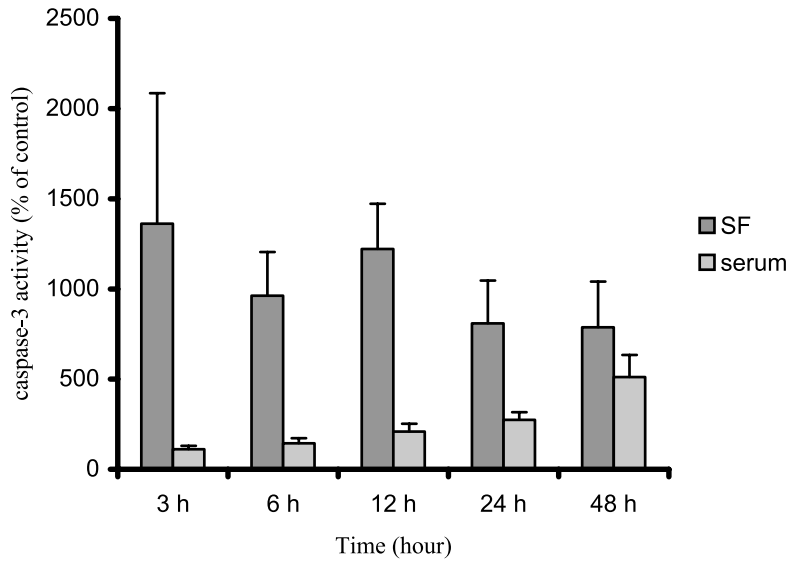

Figure 2 Time-dependent caspase-3 activity in VSMCs. Nearconfluent cells were starved in serum-free medium (SF) and harvested after $0,3,6,12,24$ and $48 \mathrm{~h}$. Caspase- 3 activity at $0 \mathrm{~h}$ was used as control. Values are given as percent of the activity at 0 h. Means \pm S.E.M.; $n=8$.

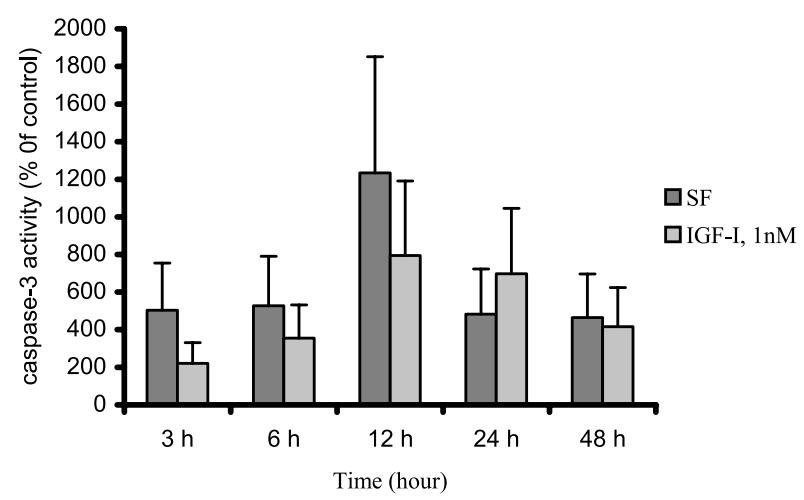

Figure 3 Time-course for inhibitory effect of IGF-I $\left(10^{-9} \mathrm{M}\right)$ on caspase- 3 activity. Confluent cells were starved in serum-free medium with or without IGF-I. Cells were also cultured with $10 \%$ NCS. Caspase- 3 activity at $0 \mathrm{~h}$ starvation was used as control. Means \pm S.E.M., $n=4$.

\section{Discussion}

We found that IGF-I and insulin had inhibitory effects on apoptosis induced by serum starvation in VSMCs. Compared with IGF-I, insulin had a weaker effect that was found at a higher concentration, $10^{-9} \mathrm{M}$ and $10^{-8}$ $M$ respectively. This suggests that the effect of insulin is elicited through the IGF-IR.

Proteolytic cleavage of cellular proteins evaluated by caspase- 3 activity showed highest activity between 3 and $12 \mathrm{~h}$ in this study. That activation of caspase- 3 occurs early in serum-deprived smooth muscle cells is supported by the observation of Shichiri et al. (2000), who found an increase in caspase- 3 activity even after $30 \mathrm{~min}$ serum deprivation of rat VSMCs. After activation of the caspase protease family, followed by cleavage of nuclear lamins and 


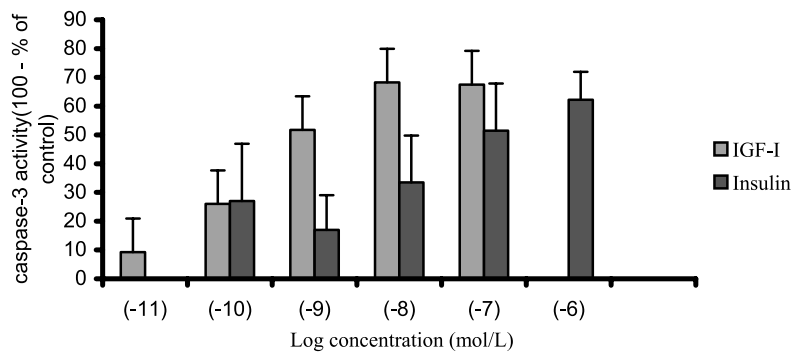

Figure 4 Evaluation of inhibitory effect of IGF-I and insulin on caspase-3 activity. Confluent cells were starved in serum-free medium and incubated for $12 \mathrm{~h}$ with insulin $\left(10^{-10}-10^{-6} \mathrm{M}\right)$ or IGF-I $\left(10^{-11}-10^{-7} \mathrm{M}\right)$. Data are given as 100 minus percent of control (starved cells). Means \pm S.E.M.; $n=4$.

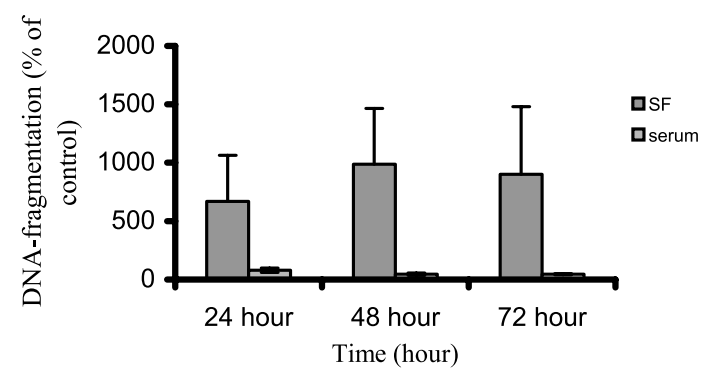

Figure 5 Time course for serum starvation-induced apoptosis in VSMCs evaluated by ELISA. Near-confluent cells were starved in serum-free (SF) medium for different times. Cells were also incubated with $10 \%$ NCS (serum). The cells were harvested after $0,24,48$ and $72 \mathrm{~h}$. Data are given as the percent at $0 \mathrm{~h}$. Means \pm S.E.M., $n=4$.

destruction of the cytoskeleton, the cells enter into an irreversible phase. Proteases mediating cell destruction are conserved in virtually all cells (Bennett 1997). Caspase-3 alone appears essential to complete the destructive phase of apoptosis (Avaughan et al. 2002). In our study, an inhibitory effect on caspase- 3 activity was found after exposure to IGF-I for 3-12 h. An inhibitory effect of IGF-I $\left(1.3 \times 10^{-8} \mathrm{M}\right)$ has previously also been reported in human VSMCs (Bai et al. 1999). Evaluation of the effect of IGF-I $\left(10^{-11}-10^{-7} \mathrm{M}\right)$ on caspase-3 activity showed that IGF-I $\left(10^{-9}-10^{-7} \mathrm{M}\right)$ inhibited caspase-3 activity. Serum starvation induced the highest apoptosis in VSMCs after $48 \mathrm{~h}$ when assessed as histone-associated DNA fragments (mono- and oligonucleosomes) by ELISA. With morphological evaluation by DAPI staining we found chromatin condensation after $24 \mathrm{~h}$ and after $48 \mathrm{~h}$ nuclear fragmentation in serum-starved VSMCs. Also caspase-3 was markedly inhibited by serum, which thus had a pronounced antiapoptotic effect. Serum contains several growth factors with possible effects on apoptosis, of which IGF-I and platelet-derived growth factor have been identified as potent survival factors (Bennett et al. 1995). Our results are consistent with previous reports of apoptosis in rabbit and human VSMCs (Pollman et al. 1996, Aoki et al. 1997, Gouni-Berthold et al. 2001). The effect of IGF-I
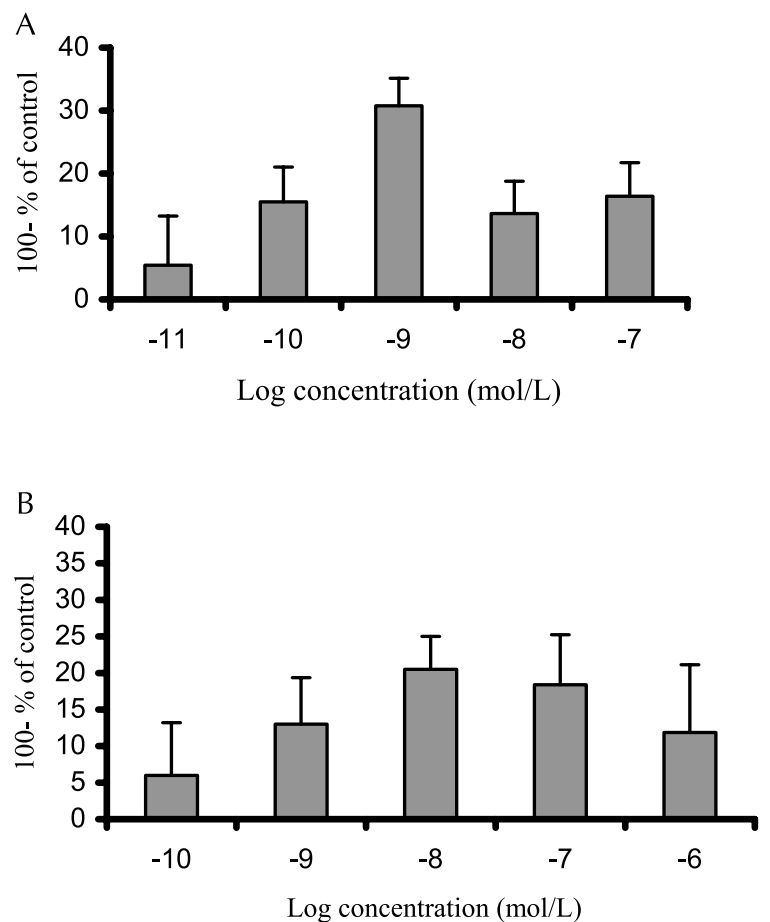

Figure 6 The effect of IGF-I and insulin on apoptosis in VSMCs evaluated by ELISA. Near-confluent cells were starved for $24 \mathrm{~h}$ and incubated with different concentration of IGF-I $\left(10^{-11}-10^{-7} \mathrm{M}\right)$ (A) or insulin $\left(10^{-10}-10^{-6} \mathrm{M}\right)$ (B) for the next $24 \mathrm{~h}$. For control, cells remained in serum-free medium. Data shown as 100 minus percent of control. Means \pm S.E.M., $n=4$.

$\left(10^{-11}-10^{-7} \mathrm{M}\right)$ on DNA fragmentation showed that IGF-I at a concentration of $10^{-9} \mathrm{M}$ had a maximal antiapoptotic effect on our cells. Jung et al. (2000) showed that $\mathrm{H}_{2} \mathrm{O}_{2}$-induced apoptosis in rat VSMCs is inhibited by IGF-I at a concentration of $10^{-9} \mathrm{M}$. Using evaluation by nuclear chromatin morphology after $12 \mathrm{~h}$ in rat VSMCs, Bai et al. (1999) found that the effect of IGF-I appeared at a concentration of $1.3 \times 10^{-10} \mathrm{M}$ and was maximal at $1.3 \times 10^{-8} \mathrm{M}$.

With the evaluation of insulin $\left(10^{-10}-10^{-6} \mathrm{M}\right)$ on caspase- 3 activity, we found that insulin $\left(10^{-6} \mathrm{M}\right)$ inhibited caspase- 3 activity significantly. To the best of our knowledge there are no previous dose-response studies on inhibition of caspase-3 activity by IGF-I or insulin in vascular smooth muscle. Goetze et al. (2001) showed that insulin $\left(10^{-6} \mathrm{M}\right)$ protects VSMCs from apoptosis. Jung et al. (2000) found that insulin $\left(10^{-7} \mathrm{M}\right)$ induces Akt phosphorylation after $30 \mathrm{~min}$ to $6 \mathrm{~h}$ in VSMCs, and inhibits apoptosis. The available data thus suggest that IGF-I inhibits apoptosis in concentrations 10-100 times lower than insulin (Jung et al. 2000).

The insulin receptor and IGF-IR are homologous and insulin and IGF-I can cross-react with each other's receptors with 100- to 1000-fold less potency than to their own receptors (Arnqvist et al. 1995). We used concentrations of 


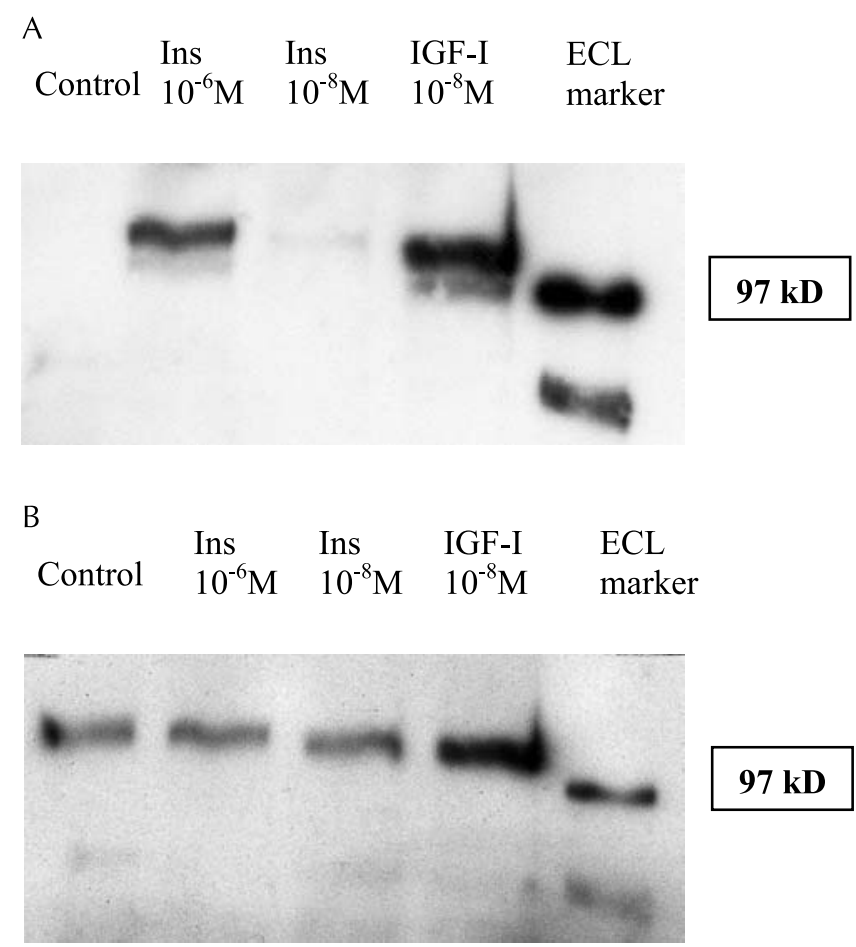

Figure 7 Phosphorylation of the IGF-IR $\beta$-subunit. Near-confluent cells were starved for $24 \mathrm{~h}$ and incubated with IGF-I $\left(10^{-8} \mathrm{M}\right)$ or insulin (Ins) $\left(10^{-8}, 10^{-6} \mathrm{M}\right)$ for $10 \mathrm{~min}$. Phosphorylation of IGF-IR was evaluated by Western blot after immunoprecipitation. (A) Shows the SDS-PAGE gel after blotting with a phosphotyrosine antibody and (B) the same gel after blotting with an antibody against the IGF-IR $\beta$-subunit. The experiment was repeated three times with similar results.

$10^{-11}-10^{-7} \mathrm{M}$ IGF-I and $10^{-10}-10^{-6} \mathrm{M}$ insulin to evaluate their effects. The circulating free IGF-I concentration is difficult to assess due to binding proteins, but is probably around $10^{-9} \mathrm{M}$ (Frystyk et al. 1994). The normal plasma insulin concentration is in the range $10^{-11}-10^{-9} \mathrm{M}$ (Olsson et al. 1988). Half-maximal displacement of labelled IGF-I from its receptor by unlabelled IGF-I is obtained at $0 \cdot 3 \times 10^{-9} \mathrm{M}$ (Bornfeldt et al. 1991) and the corresponding concentration for displacement of labelled insulin from its receptor by unlabelled insulin is around $10^{-11} \mathrm{M}$ (Kurtzhals et al. 2000). We found that IGF-I $\left(10^{-8} \mathrm{M}\right)$, and at a very high unphysiological concentration also insulin $\left(10^{-6} \mathrm{M}\right)$ phosphorylated the IGF-IRs. This observation is in agreement with Banskota et al. (1989), who found that insulin $\left(1.6 \times 10^{-7} \mathrm{M}\right)$ and IGF-I $\left(1.3 \times 10^{-8} \mathrm{M}\right)$ stimulate c-myc, and who demonstrated that the effects of insulin and IGF-I on DNA synthesis and proliferation of human smooth muscle cells occur via the IGF-IR. Specific binding of insulin in cultured VSMCs has been found to be very low, and affinity cross-linking studies have not been able to demonstrate specific insulin receptors (Jialal et al. 1985, King et al. 1985). Insulin stimulates metabolism in isolated arteries, but is approximately 100 times less potent in arterial smooth muscle compared with skeletal muscle (Arnqvist 1974). Ruiz-Torres et al. (1998) showed that under special conditions that also occur with ageing, insulin interacts with receptors in VSMCs, especially IGF-I, stimulating these cells to produce collagen. Thus there are several lines of evidence suggesting that the metabolic effects of insulin on VSMCs observed in vitro are elicited through IGF-IRs. Our results suggest that also the inhibitory effects of IGF-I and insulin on apoptosis in VSMCs probably are mediated through IGF-IRs. The effects of insulin are only found at insulin concentrations which are much higher than those that occur in vivo, indicating that the effect of insulin can only be obtained in vitro. From a clinical point of view, our results suggesting that IGF-I but not insulin inhibits apoptosis in VSMCs is of great interest. In patients with type 1 diabetes, IGF-I levels are low, and largely independent of glycaemic control, probably due to lack of insulin delivery to the liver in the portal vein (Hanaire-Broutin et al. 1996, Ekman et al. 2000). Low circulating IGF-I could increase apoptosis and thereby promote vascular disease. 


\section{Acknowledgements}

We are grateful to Mrs Karin Roberg, Lena Trulsson and Simin Mohseni for their advice. Financial supported was obtained from the Swedish Medical Research Council (4952), the Swedish Diabetes Association, Barndiabetesfonden and the County of Östergötland.

\section{References}

Aoki M, Morishita R, Matsushita H, Nakano N, Hayashi SI, Tomita N, Yamamoto K, Moriguchi A, Higaki J \& Ogihara T 1997 Serum deprivation-induced apoptosis accompanied by up-regulation of P53 and bax in human aortic vascular smooth muscle cells. Heart and Vessels. Supplement 12 71-75.

Arnqvist HJ 1974 Action of insulin on vascular and intestinal smooth muscle. Effects on amino acid transport, protein synthesis and accumulation of glucose carbon. Acta Physiologica Scandinavica 90 132-142.

Arnqvist HJ, Bornfeldt KE, Chen Y \& Lindström T 1995 The insulin-like growth factor system in vascular smooth muscle: interaction with insulin and growth factors. Metabolism 44 58-66.

Avaughan ATM, Betti W \& Villalobos MJ 2002 Surviving apoptosis. Apoptosis 7 173-177.

Bai HZ, Pollman MJ, Inishi Y \& Gibbons GH 1999 Regulation of vascular smooth muscle cell apoptosis. Modulation of Bad by a phosphatidylinositol 3-kinase-dependent pathway. Circulation Research 85 229-237.

Banskota NK, Taub R, Zellner K, Olsen P \& King GL 1989 Characterization of induction of proto-oncogene c-myc and cellular growth in human smooth muscle cells by insulin and IGF-I. Diabetes 38 123-129.

Bennett MR 1997 Apoptosis in vascular disease. Transplant Immunology 5 184-188.

Bennett MR \& Boyle JJ 1998 Apoptosis of vascular smooth muscle cells in atherosclerosis. Atherosclerosis 138 3-9.

Bennett MR, Evan GI \& Schwartz SM 1995 Apoptosis in human vascular smooth muscle cells derived from vessels and coronary atherosclerotic plaques. Journal of Clinical Investigation 95 2266-2274.

Bornfeldt KE, Gidlöf RA, Wasteson A, Lake M, Skottner A \& Arnqvist HJ 1991 Binding and biological effects of insulin, insulin analogues and insulin-like growth factors in rat aortic smooth muscle cells. Comparison of maximal growth promoting activities. Diabetologia 34 307-313.

Chinnaiyan AM \& Dixit V 1996 The cell-death machine. Current Biology 6 555-562.

Cohen JJ 1994 Apoptosis: physiologic cell death. Journal of Laboratory and Clinical Medicine 124 761-765.

Davies MJ 1996 Stability and instability: two faces of coronary atherosclerosis. Circulation 94 2013-2020.

Davies MJ, Richardson PD, Woolf N, Katz DR \& Mann J 1993 Risk of thrombosis in human atherosclerotic plaques: role of extracellular lipid, macrophage, and smooth muscle cell content. British Heart Journal 69 377-381.

Donnelly R, Emslie-Smith AM, Gardner ID \& Morris AD 2000 Vascular complications of diabetes. British Medical Journal $\mathbf{3 2 0}$ 1062-1066.

Ekman B, Nyström F \& Arnqvist HJ 2000 Circulating IGF-I concentrations are low and not correlated to glycaemic control in adults with type 1 diabetes. European Journal of Endocrinology 143 305-310.

Frystyk J, Skjærbæk C, Dinesen B \& Ørskov H 1994 Free insulin-like growth factors (IGF-I and IGF-II) in human serum. FEBS Letters 348 185-191.

Gabbiani G, Schmid E, Winter S, Chaponnier C, De Chastony C, Vandekerckhove J, Weber K \& Franke WW 1981 Vascular smooth muscle cells differ from other smooth muscle cells: predominant of vimentin filaments and a specific $\alpha$-type actin. PNAS 78 298-302.

Goetze S, Blaschke F, Stawowy P, Bruemmer D, Spencer C, Graf K, Gräfe M, Law RE \& Flek E 2001 TNF $\alpha$ inhibits insulin antiapoptotic signalling in vascular smooth muscle cells. Biochemical and Biophysical Research Communications 287 662-670.

Gouni-Berthold I, Berthold HK, Weber AA, Ko Y, Seul C, Vetter H \& Sachinidis A 2001 Troglitazone and rosiglitazone induce apoptosis of vascular smooth muscle cells through an extracellular signal-regulated kinase-independent pathway. Naunyn Schmiedebergís Archives of Pharmacology 363 215-221.

Hall JL, Matter CM, Wang X \& Gibbons GH 2000 Hyperglycemia inhibits vascular smooth muscle cells apoptosis: mediator role of protein kinase C. Circulation Research 87 574-580.

Hanaire-Broutin H, Sallerin-Caute B, Poncet MF, Tauber M, Bastide R, Chalé JJ, Rosenfeld R \& Tauber JP 1996 Effect of intraperitoneal insulin delivery on growth hormone binding protein, insulin-like growth factor(IGF)-I, and IGF-binding protein-3 in IDDM. Diabetologia 39 1498-1504.

Janicke RU, Sprengart ML, Wati MR \& Porter AG 1998 Caspase-3 is required for DNA fragmentation and morphological changes associated with apoptosis. Journal of Biological Chemistry 273 9357-9360.

Jialal I, Crettaz M, Hachiya HL, Kahn CR, Moses AC, Buzney SM \& King GL 1985 Characterization of the receptors for insulin and insulin-like growth factors on micro-and macrovascular tissues. Endocrinology 117 1222-1229.

Jung F, Haendeler J, Goebel C, Zeiher AM \& Dimmeler S 2000 Growth factor-induced phosphoinoside 3-OH kinase/Akt phosphorylation in smooth muscle cells: induction of cell proliferation and inhibition of cell death. Cardiovascular Research $\mathbf{4 8}$ $148-157$.

Kidd VJ 1998 Proteolytic activities that mediate apoptosis. Annual Review of Physiology 60 533-573.

King GL, Goodman AD, Buzney S, Moses A \& Kahn CR 1985 Receptors and growth-promoting effects of insulin and insulin-like growth factors on cells from bovine retinal capillaries and aorta. Journal of Clinical Investigation 75 1028-1036.

Kurtzhals P, Schäffer L, Sørensen A, Kristensen C, Jonassen I, Schmid C \& Trüb T 2000 Correlations of receptor binding and metabolic and mitogenic potencies of insulin analogs designed for clinical use. Diabetes 49 999-1005.

Lee PDK, Hintz RL, Rosenfeld RG \& Benitz WE 1988 Presence of insulin like growth factor receptors and lack of insulin receptors on fetal bovine smooth muscle cells. In Vitro Cellular and Developmental Biology 24 921-926.

Lowry OH, Rosebrough NJ, Farr AL \& Randall RJ 1951 Protein measurement with the Folin phenol reagent. Journal of Biological Chemistry 193 265-275.

McCarthy NJ \& Bennett MR 2000 The regulation of vascular smooth muscle cell apoptosis. Cardiovascular Research 45 747-755.

Nilsson J, Ksiazek T, Heldin C \& Thyberg J 1983 Effects of colchicines on DNA synthesis, endocytosis and fine structure of cultured arterial smooth muscle cells. Experimental Cell Research 143 367-375.

Okura Y, Brink M, Zahid AA, Anwar A \& Delafontanine P 2001 Decreased expression of insulin-like growth factor-I and apoptosis of vascular smooth muscle cells in human atherosclerotic plaque. Journal of Molecular and Cellular Cardiology 33 1777-1789.

Olsson PO, Arnqvist HJ \& von Schenck H 1988 Free insulin profiles during subcutaneous insulin regimens in diabetes mellitus type 1. Diabete et Metabolisme 14 253-258.

Peruzzi F, Prisco M, Dews M, Salomoni P, Grassilli E, Romano G, Calabretta B \& Baserga R 1999 Multiple signalling pathways of the insulin-like growth factor-I receptor in protection from apoptosis. Molecular and Cellular Biology 19 7203-7215. 
Podesta F, Romeo G, Liu WH, Krajewski S, Reed JC, Gerhardinger C \& Lorenzi M 2000 Bax is increased in the retina of diabetic subjects and is associated with pericyte apoptosis in vivo and in vitro. American Journal of Pathology 156 1025-1032.

Pollman MJ, Yamada T, Horiuchi M \& Gibbons GH 1996 Vasoactive substances regulate vascular smooth muscle cell apoptosis. Circulation Research 79 748-756.

Resnicoff M, Coppola D, Sell C, Rubin R, Ferrone S \& Baserga R 1994 Growth inhibition of human melanoma cells in nude mice by antisense strategies to the type 1 insulin-like growth factor receptor. Cancer Research 54 4848-4850.

Ross R 1971 The smooth muscle cell. II. Growth of smooth muscle in culture and formation of elastic fibers. Journal of Cell Biology $\mathbf{5 0}$ 172-186.

Ruiz-Torres A, Melon J \& Munoz FJ 1998 Insulin stimulates collagen synthesis in VSMC from elderly patients. Gerontology 44 144-148.

Saini KS \& Walker NI 1998 Biochemical and molecular mechanisms regulating apoptosis. Molecular and Cellular Biochemistry 178 $9-25$.
Shichiri M, Yokokura M, Marumo F \& Hirata Y 2000 Endothelin-1 inhibits apoptosis of vascular smooth cells induced by nitric oxide and serum deprivation via MAP kinase pathway. Arteriosclerosis, Thrombosis, and Vascular Biology 20 989-997.

Skalli O, Rapraz P, Trzeciak A, Benzonana G, Gillessen D \& Gabbiani G 1986 A monoclonal antibody against $\alpha$-smooth actin: a new probe for smooth muscle differentiation. Journal of Cell Biology $1032787-2796$.

Thornberry NA, Rano TA, Peterson EP, Rasper DM, Timkey T, Garcia-Calvo M, Houtzager VM, Nordstrom PA, Roy S, Vaillaancourt JP et al. 1997 A combinatorial approach defines specificities of members of the caspase family and granzyme B. Functional relationships established for key mediators of apoptosis. Journal of Biological Chemistry 272 17907-17911.

Received 2 July 2003

Accepted 17 July 2003

Made available online as an

Accepted Preprint 4 August 2003 